гическомь изсльдовапіи въ случаяхъ труднаго расиознаванія бользни. Благодаря этолу способу, ему много разъ удавалось ставпгь вырный діагнозъ там'ь, гдъ при обыкновенномь положеніи больныхъ на спин' не.льзя бы.то составить даже приблизительнаго повятія о состоянін оргавовъ малаго таза.

\title{
Н. Алексенко.
}

\section{3. Е. Ф. Бацевичъ. Причины септическихъ посльродовыхъ заболь- ваній. - Антисептика. Асептина (Изъ серіи лекцій, прочитанныхъ анушеркамъ въ аудиторіи Импер. Техническаго Общества). Спб., 1891; 75 стр., пьна 50 кош.).}

Авторъ, прочитавшій въ истектемъ учебномъ году цблый повторительный курсъ для повивальныхъ бабокъ, выпустилъ въ св'ътъ рефервруеную брошюру; заключающую въ себъ его лекціи объ этіологіи септическихъ посльродовыхъ забольвавіи и о шърахъ борьбы съ вими. Находя совершевво справедливо, qт0 научиться прим'вненію противогнилостнаго щетода можно только практическимъ путемъ, а не изъ теоретическаго изложевія, авторъ поставилъ себъ задаqею, если не научить своихъ слушательницъ, то по крайней мьръ убъдимь ихъ въ значеніи антисептики, для qего онъ довольно подробно останавливается на исторіи ея возникновенія и дальньйmаго развитія, вб0 взъ эгой исторів, по его собственнымъ словамъ, "необходимость автисептики вытекаетъ, какъ едивственно возиожный выводъ».

Коснувпись въ общихъ чертахъ господствовавшахъ въ раз.личныя времена гипотезъ относительно пропсхожденія и сущвости такъ вазываеиой родильной горячки, авторъ переходитъ къ Semmetweis'у и весьма обстоятельно излагаетъ исторію той борьбы, которую посльднему приплось вынести ва свовхъ плечахъ изъ-за проповъдуемыхъ имъ идей. Далье, упомянувъ объ изв Һсстныхъ изсл'ьдованіяхъ Pasteur'a относвте.льн процессовъ гвіенія, авторъ переходитъ къ изложенію ученія о шикрорганизмазъ, ихъ распространенности, классификадіи и біологіи различныхъ видовъ шхъ. Затьщъ, сказавъ н'ъсколько словъ 0 заслугахъ Lister'a въ хирургпческой антисештик', во-

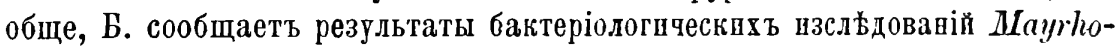
fer'a, Hausman'a, Heberg'a, Orth'a, Waldeyer'a, Pasteur'a, Doleris в др. въ области посльродовыхъ забольваній, посль чего овъ вкратць взлагаетъ современное учевіе о происхожденіи, какъ мъствыгъ посльродовызъ процессовъ, такъ и общаго септическаго заражевія въ связи съ жнзнедЊятельностью микроорганизыовъ (птомаины); далъе авторъ касается благопріятствующихъ забольванію родильницъ условій, фшзвqескихъ и психическихъ, средствъ борьбы организыа съ заразвыљ началомъ (Мечниковъ) п взанмнаго отношенія гнилостныхъ и бользнетворныхъ микропрганизщовъ.

Вторая половина бропюры трактуеть о методикБ противогнилостнаго снособа въ прищьневіи къ акушерству. Прежде всего Ь. условливается относительво терминологіи: антиселтику овъ опред'ылетъ, какъ совокупносгь пріемов'ъ, имъющщхх свовм назначевіещъ пренятствовать поступлевію въ тыло человька микроорганизмовъ и увичтожать уже поступивпіе; асептика 
равнозначуща отсутствію микроорганизмовъ и борьбы съ ними; другими словами, антисептика есть средство, которымъ мы стренися достигнуть асептики, какъ конеqной цъли; сльддовательно, автисептика есть синонимъ дезинфекціи (жеханической, химической, термической). Изложивъ антисептическое звачевіе мытья, пров'ьтриванія, высокой температуры (сухой и влажной) и различныхъ химическихъ дезивфецирующихъ средствъ на основаніи бактеріоскопическихъ изслъдованій, авторъ подробно останавливается ва техник' ихъ дримъненія съ щълью обеззараженія акушерскаго персонала, его одежды (передники), рукъ (правила, преподанныя Fïrbringer'омъ); родильной комнаты, бълья, инструментовъ и пр., причемъ даеть много весьма практичныхъ сов'товъ. Нельзя не упомянуть о положеніи автора, что, если врачт или акушерка имьли дьло съ септическиыъ забольваніемъ, то достаточво посль этого самымъ строгия и педантичнымъ образомъ обеззаразиться, и нбтт надобности, какъ этого требуютъ многіе, воздерживаться втеqеніе $2-3$ недъљь

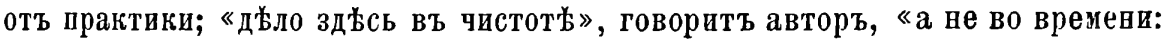
время, къ сожал'ьнію, не имъетъ антисептическихъ свойствъ .

Далъе Б. подробво говоритъ о приньненіи обеззараживающихъ спринцевавій у беремепныхъ, роженицъ и родильницъ. Заканчивается брошюра описаніемъ важнъйшихъ дезивфецирующихъ средствъ, способовъ ихъ употребленія и дњйствія, признаковъ отравленія ими и льччевія отравлевій.

\section{А. Фишеръ.}

\section{4. А. А. Ануфріевъ. Къ вопросу о прим} прантинь. (Русская Медицива, 1891, ㄲo 1, 2, 3 и 5).

Предпославъ краткій историческій очеркъ о примъневіи сулемы въ акушерской и гивекологической практикъ, авторъ задается цЊлью обрисовать положевіе сулемы, какъ антисептическаго средства и ръпить вопросъ: м0жетъ ли сулема и теперь играть роль антисептическаго средства въ акушерской практикъ? Суть этого вопроса овъ сводитъ къ тремъ пунктамъ: сулема, какъ одинъ изъ способовъ для безгнияостнаго течевія нормальныхъ и патологическихъ родовъ; сулема, какъ автисептическое средство при послћродовыхъ забольвавіяхъ, и сулема, какъ ядовитое средств 0 , дъйствующее вредно на кровь и ткани родильницъ.

На 1402 родовъ, въ которыхъ въ 4 года съ 1885 по 1888 годъ въ клиникњ Варшавскаго Университета примънялась сулема, приходится 12 случаевъ $\left(0,85^{\circ} \%\right)$ ивтоксикаціи ею. Обыкновенно сулема употреблялась въ раствор $1: 3000$. Примжнялся растворъ сулемы въ виды влагалищваго соринцованія при поступлевіи роженицы и предъ каждым изсльдованіеыъ ея. Посль родовъ 2 раза въ день растворомъ сулемы производилось обмывавіе наружныхъ половыхъ частей. Посль акушерскихъ операцій матка промывалась растворомъ сулемы $1: 3000$ въ количеств' не превышающемъ 2 латровъ. Посл'店каждой такой ввутриматочной ивъекціи полость матки промывалась раствороыъ acidi carbolici $2 \%$ для удаленія оставпейся сулемы и съ ц'Влью устранить образовавіе растворимыхъ альбуминатовъ. Въ нькоторыхъ 